\title{
PICTURE WORD INDUCTIVE MODEL FOR BETTER DESCRIPTIVE TEXT WRITING
}

\author{
Mira Ermita \\ Department of Language Education, Universitas Negeri Jakarta, Indonesia \\ E-mail: miraermita_lt15s3@mahasiswa.unj.ac.id \\ Emzir \\ Department of Language Education, Universitas Negeri Jakarta, Indonesia \\ E-mail: emzir.unj@unj.ac.id \\ Ninuk Lustyantie \\ Department of Language Education, Universitas Negeri Jakarta, Indonesia \\ E-mail: ninuk.lustyantie@unj.ac.id
}

\begin{abstract}
APA Citation: Ermita, M., Emzir, E., \& Lustyantie, N. (2019). Picture word inductive model for better descriptive text writing. Indonesian EFL Journal, 5(2), 73-84. doi: 10.25134/ieflj.v5i2.1736.
\end{abstract}

Received: 19-03-2019

Accepted: 12-05-2019

Published: 01-07-2019

\begin{abstract}
This study is done to find out the effect of using the Picture Word Inductive Model for teachinglearning descriptive text with second-semester students in the English Education Study Program at the University of Jambi in Indonesia to improve the students' writing skills. This study used an action research method. Three cycles were done in this study. Data were gathered from observations and tests. In the preliminary study, the mean score of the student's speaking was 50 . The percentage of students who passed the minimum criterion of 70 was $6 \%$ with only 1 out of 17 students passing the minimum score. The mean score from cycle 1 was 72 and only 11 students or $65 \%$ passed the minimum score. The mean score from cycle 2 was 67 and $41 \%$, i.e. only 7 students passed the minimum score. Meanwhile, from cycle 3, the mean score was 80 and all of the students $(100 \%)$ passed the minimum score. Hence, the results showed that the use of Picture Word Inductive Model was a success. The students enjoyed their lessons more and were more motivated, interested and confident during the teaching-learning sessions.
\end{abstract}

Keywords: action research; descriptive text; Picture Word Inductive Model; writing skill.

\section{INTRODUCTION}

In this global area, learning and mastering English as one of the global communication tools is extremely important in order to build a good relationship globally (Fadhly, Hasanah, \& Agustiana, 2017; Rohmat \& Sadikin, 2019; Syarifah \& Emiliasari, 2019). As a means of communication, English can be done in written and spoken form (Budiharto, 2019). Chanyoo (2018) argues that writing skills is one way of communicating that cannot be separated from human life. Writing usually reinforces learning, thinking, and reflecting language as a mode of communication. Having automatic writing skills will have the potential to write. Writing is a form of communication that allows students to put their feelings and ideas on paper, to organize their knowledge and beliefs into convincing arguments, and to convey meaning through well-constructed text. In its most advanced form, written expression can be as vivid as a work of art.

Writing is considered as one of the important components of applied linguistics (Abbas \& Tawfeeq, 2018) and one of four important language skills and must be studied by EFL students (Ratminingsih, Marhaeni, \& Vigayanti, 2018). Writing activities are an integral part of the entire learning process (Nurdianingsih, 2018). Writing can be the main criterion towards a better academic position and greater educational success (Kamariah, Husain, Atmowardoyo, \& Salija, 2018). Writing is important parts of everyday life, and it is 
involved in many situations where a series of symbols convey meaning with multiple purposes. Niño and Páez (2018) stated that writing is a process related to how learners develop their language skills because it is possible to make the progress of language learning truly proven when writing production increases. Meanwhile, Urrutia and Gutierrez (2011) argued that writing is more than the production of graphic symbols but must consider formal aspects, so that it is coherent. Writing is important for sharing ideas and feelings, and convincing others. Writing is a complex activity both from the point of view of teaching and learning. Writing does not merely compile or compose words, phrases and sentences but writing must follow certain language rules in order to produce writings that are understood and accepted by the community (Jam \& Shahin, 2012).

Spelling, vocabulary, grammar, and organization come together and grow together to help the student demonstrate more advanced writing skills each year (Soviyah \& Etikaningsih, 2018). The written form can be done using written text such as sending message, email, or text. Aljatila (2015) states that what is meant in writing skills is the skill of using spelling, punctuation, word formation, use of sentences, selection of sentences, selection of effective sentences, expressing thoughts carefully, precisely, logically, and consistently. An effective writing is the writing had been well and carefully compiled, so that the reader could understand the message, news, and message conveyed in the article. Achieving effectiveness in the writing, a writer must pay close attention to language problems, spelling, and choice of words.

There are many kinds of genre text. One of them is descriptive text. Descriptive text is one of the basic functions of each language system and one of the first skills that arise and can be controlled by language users. This is also one of the most widely used genres in all fields of learning. Descriptions allow the categorization or classification of almost unlimited experiences, observations, and interactions into a system and allow us to find out whether objectively or subjectively, depending on the learning area or the intent of the author. Descriptions are also used widely in many types of texts, namely: (1) information reports, (2) literary descriptions, (3) descriptive recounts, and (4) classifying and/or describes a process (Knapp and Watkins, 2005)

Descriptive writing is a type of writing with the aim of providing information. The context of this type of writing is a description of certain things, such as animals, people, or other people, such as our pets or someone we know well. The social function of descriptive writing is to describe certain people, places, or things. According to Finoza (2013) the description is collected from description English which of course relates to the verb to describe (describing with language). Description essays are essays that purpose is to provide details or details about objects so that they can influence emotions and create the reader's imagination like seeing, hearing, or feeling directly what the writer is saying (Aji, 2013). Dadi (2015) states descriptive writing is a type of writing that describes or shows something rather than telling it. Descriptive writing can describe people, feelings, sounds, places, processes, qualities, or procedures in detail. Writing this text needs knowledge and skill. The students need to understand the generic structure, linguistic features, and social function of descriptive text to write it.

According to Miy (2012) good descriptive paragraphs have the following characteristics: (1) provide clear information about the place, object, or person that is described; (2) provide detailed explanations in the body of the paragraph; (3) complete the paragraph with recommendations or comments about the object described (Table 1); (4) using the present tense or past tense; and (5) the use of clear words and adjectives. Aljatila (2015) states generally the characteristics of descriptive writing according to experts are (1) describing or describing objects; (2) containing details of 
objects; (3) making readers or listeners feel themselves or experiencing themselves; and (4) results absorption of the five senses. Knapp and Watkins (2005) also explained that in a descriptive writing, paragraphs must have grammar features of describing such as: (1) using present tense when describing things about technical or point of view; (2) although the present tense can be used in literal descriptions, past tense can also be used; (3) relational verbs are used when classifying and describing the appearance,

\section{https://journal.uniku.ac.id/index.php/IEFLJ/index}

quality and part or function of a thing; (4) action verbs are used when describing behavior or being used; (5) mental verbs are used when describing feelings; (6) adjectives can be used as part of a noun; (7) adverbs are used to add information to verbs to add detailed descriptions; (8) adverb groups are used in descriptions to add information about ways, places or times; and (9) sentences and paragraphs are thematically related to the topic of the description.

Table 1. Schematic structure of descriptive text (Miy, 2012)

\begin{tabular}{ll}
\hline \multicolumn{1}{c}{ Schematic Structure } & Function \\
\hline Introducing & $\begin{array}{l}\text { First paragraph contains the name of the place and location and the } \\
\text { reasons for choosing the theme. } \\
\text { Body } \\
\text { The second paragraph we usually write about is what the theme or } \\
\text { idea is like. The third paragraph describes the theme in detail and } \\
\text { includes things that can be seen, felt, heard, smell. In the main body } \\
\text { there are complementary sentences that function as supporting } \\
\text { sentences. Sources in conveying information to readers are also } \\
\text { needed, because with the source of the reader more confident in the } \\
\text { information submitted. } \\
\text { The conclusion is a summary of the important things discussed in the } \\
\text { body of text. }\end{array}$ \\
\hline
\end{tabular}

However, the students of second semester of English Education Study Program of University of Jambi faced some problems in writing. They looked bored in writing the text. They were not interested and motivated in the writing activities. They also lack of vocabulary. Moreover, they have confusion in the use of grammar. Furthermore, they were unable to write sentences and paragraphs in English.

Picture Word Inductive Model (PWIM) was chosen as a model to solve the problem. It helps students to improve writing skills because it can increase vocabulary acquisition (Mcdonald, 2010; Swartzendruber, 2007). PWIM helps ELLs practice spelling, phonics and grammar (Shaman, 2014). PWIM improved students English vocabulary and students able to compose meaningful English paragraph. As well as students motivation toward learning English (Feng, 2011). PWIM is used by English teachers to get better scores and as an alternative technique for teaching writing skills (Suraya, 2017). PWIM can improve students' descriptive text writing (Muttaqin, 2015; Nurani \& Rosyada, 2017). PWIM has a significant effect on students' descriptive text writing skills (Sepyanda, 2013). The previous research applied PWIM in specific elements of writing such as mechanism or just limited on grammatical feature. Yet, in this research PWIM was applied on the three elements of writing; text structure, language features, and diction.

Overall, there are some advantages to using PWIM. Yuniyarsih and Saun (2014) mentioned five benefit of using PWIM in writing class; (1) PWIM provides concrete visuals to learn new words, phrases, and sentences. This model also provides interesting visuals to make it easier for students to learn new words, expressions, and also make sentences. Because students use images that relate to topics or materials and label together images, they will feel that they are part of the class community and the confidence to participate in class activities. Students as part of the community can have confidence and will be happy to participate in 
the class. (2) PWIM teaches students how to ask the structure of words and sentences based on labeled images. So, students can classify words into various groups of words. (3) Students are helped to see the pattern and relationship of English, which allows them to apply this learning to find new words. Using PWIM can help students make sentences using new words in the picture and also try to create an understanding of the connection of reading or writing. (4) Using PWIM students can benefit from teacher modeling of keywords and concepts. With practice, they can learn to make sentences and paragraphs related to the subject. (5) PWIM can help the teacher to provide curricular and instructional balance better by focusing the lesson to arrange and understand the subject.

PWIM has 10 main activities in the learning process of writing paragraphs, namely: (1) Select an image, for the selection of images, it must be noted that the selected image is a familiar picture with students. (2) Identify parts of the image. In this stage, the students tried to identify some words related with the pictures given by the teacher. (3) Label (word) the part of the image that has been identified. (4) Reading and reviewing. (5) Students read the word. (6) Read and review again. (7) Add words. (8) Give the picture title. (9) Make sentences and paragraphs. (10) Read and review sentences or paragraphs (Joyce, Weil, \& Calhoun, 2009). Therefore, this study was conducted to discover the students' writing improvement especially in descriptive text through the implementation of PWIM.

\section{METHOD}

This research was an action research which was emphasized in improving students' writing skill. It was a descriptive qualitative research. The nature of this action research was collaborative which involved the English teacher as the collaborator and the researcher herself. Based on these considerations, in this study, the researcher used collaborative action research in which she co-operated with one of the English lecturers from the English Education Study Program at the
University of Jambi. The lecturer acted as the researcher and also as an observer on the implementation of PWIM in writing class while the collaborator acted as an independent observer who observed both the researcher and the participants. The lecturer was an active participant who not only functioned as an observer but also participated in taking actions by making the lesson plans and by giving assessments. Then, she collected and analyzed the data together with the collaborator.

Researcher used a design developed by Riel in Mertler (2009) implemented in three cycles each of which involved four steps in this modeling method of research namely: consisted of four main strategy, study and planning are needed. Problems were determined based on the empirical experience found every day. After the problem was identified, then appropriate actions are planned to overcome the problem and be able to be carried out by the researcher. Action support devices (media and Semester Learning Plans) are prepared at the planning stage. The next stage was implementing the action, then collecting data / information and analyzing. The evaluation results were then analyzed, evaluated and responded to. Activities are carried out until problems can be overcome.

The subjects of the research were 17 students second semester of English Education Study Program at University of Jambi, Indonesia. It was chosen because the students in the class had problem in writing skill. Based on the interview conducted with the writing lecturer it was found that there were five problems encountered by the students of English Education Study Program at University of Jambi. The researcher interviewed the head of the English Education Study Program at University of Jambi related with writing ability; namely (1) the previous school had not provided learning of English writing specifically which referred to the improvement of English writing skills; (2) the lack of student vocabulary knowledge, so students still have difficulty in determining the appropriate 
vocabulary; (3) students experience difficulties in using grammar when given the task of making a sentence and forming a paragraph; (4) students have not been able to write sentences and paragraphs in English comprehensively; and (5) students are still very dependent on the internet in completing assignments given by lecturers.
https://journal.uniku.ac.id/index.php/IEFLJ/index

Pre-test and post-test were used as the instruments to collect the quantitative data. After the data were collected, the researcher assessed the result of the tests using the scoring rubric adopted from Weigle (2002), Anderson and Anderson (1997), Derewianka (2000), Emilia (2010), and Knapp and Watkins (2005) provided in Table 2.

\section{Table 2. The scoring rubric for descriptive writing text}

\begin{tabular}{|c|c|c|}
\hline \multicolumn{2}{|c|}{ The Text Structure } & \multirow{2}{*}{$\begin{array}{c}\text { Score } \\
4\end{array}$} \\
\hline a. & $\begin{array}{l}\text { General opening statement is in the first paragraph. This statement tells the reader what } \\
\text { the text contains, including a brief description of the subject, and includes the definition } \\
\text { of the subject. }\end{array}$ & \\
\hline b. & $\begin{array}{l}\text { Each paragraph starts with a topic sentence. The topic sentence at the beginning of each } \\
\text { paragraph provides information contained in the paragraph. The sentence after this } \\
\text { preview provides further details. Each paragraph must provide information about the } \\
\text { subject. These paragraphs build a description of the subject. This paragraph can include } \\
\text { technical language related to the subject. }\end{array}$ & \\
\hline c. & $\begin{array}{l}\text { The closing paragraph signifies the end of the text and this paragraph can summarize in } \\
\text { its entirety. }\end{array}$ & \\
\hline a. & $\begin{array}{l}\text { This statement tells the reader what the text contains, including a brief description of the } \\
\text { subject, and includes the definition of the subject. }\end{array}$ & 3 \\
\hline b. & $\begin{array}{l}\text { Each paragraph must provide information about the subject. These paragraphs build a } \\
\text { description of the subject. This paragraph can include technical language related to the } \\
\text { subject. }\end{array}$ & \\
\hline c. & A very concise conclusion in a paragraph. & \\
\hline a. & Includes a brief description of the subject, and includes the definition of the subject. & 2 \\
\hline b. & $\begin{array}{l}\text { These paragraphs build a description of the subject. This paragraph can include technical } \\
\text { language related to the subject. }\end{array}$ & \\
\hline & A simple closing paragraph. & \\
\hline a. & Covers the definition of the subject. & 1 \\
\hline & Only includes technical language related to the subject. & \\
\hline & A simple closing sentence. & \\
\hline \multicolumn{3}{|c|}{ Language Feature } \\
\hline a. & Posts in the present tense or past tense. & 4 \\
\hline b. & Using action verbs, process verbs, adjectives, factual and appropriate languages. & \\
\hline c. & Language to define, classify, compare and construct, formal and objective writing styles. & \\
\hline a. & Posts in the present tense or past tense. & 3 \\
\hline b. & Using action verbs and adjectives, factual and precise languages, & \\
\hline c. & Language to define, classify, compare and construct, formal and objective writing styles. & \\
\hline & Posts in the present tense or past tense. & 2 \\
\hline & Use verb actions and adjectives. & \\
\hline c. & Language defines and compares formal and objective writing styles. & \\
\hline & Posts in the present tense or past tense. & 1 \\
\hline & Not using action verbs and adjectives. & \\
\hline & Language does not define and compare. & \\
\hline \multicolumn{3}{|c|}{ Diction } \\
\hline & Choose the right and harmonious words to express ideas in paragraphs. & 4 \\
\hline b. & Providing targets for effective communication to readers. & \\
\hline a. & The word chosen is quite aligned to express ideas in paragraphs. & 3 \\
\hline b. & Enough words can provide the target of effective communication to the reader. & \\
\hline & Choose words that are less precise and do not express ideas in paragraphs. & 2 \\
\hline b. & Cannot provide effective communication targets to readers. & \\
\hline & The chosen word is incorrect and not aligned to express ideas in paragraphs. & 1 \\
\hline & Diction cannot provide the target of effective communication to the reader. & \\
\hline
\end{tabular}


To find the students' score the following formula was used:

Score $=\frac{\text { Number of students'score }}{\text { Maximal score }} \times 100$
Thus, the results shown in Table 3 . Meanwhile, to find out the students' score based on the category, the range score presented in Table 4 is used.

Table 3. The convert score

\begin{tabular}{ccc}
\hline Students' point & Maximum Score & Score \\
\hline 1 & 12 & 8 \\
2 & 12 & 17 \\
3 & 12 & 25 \\
4 & 12 & 33 \\
5 & 12 & 42 \\
6 & 12 & 50 \\
7 & 12 & 58 \\
8 & 12 & 67 \\
9 & 12 & 75 \\
10 & 12 & 83 \\
11 & 12 & 92 \\
12 & 12 & 100 \\
\hline
\end{tabular}

Table 4. Score category

\begin{tabular}{cc}
\hline Category of Final Score & Category \\
\hline $85-100$ & Vey Good \\
$70-84$ & Good \\
$60-69$ & Fair \\
$50-59$ & Poor \\
$0-49$ & Extremely Poor \\
\hline
\end{tabular}

\section{RESULTS AND DISCUSSION Result from observation}

In doing this research, the researcher acted as a teacher and delivered the teaching and learning process. The English teacher acted as the collaborator and observed the teaching and learning process. There were two cycles in this research. Each cycle consisted of three meetings. At the end of each cycle, the researcher did the reflection. Each cycle consisted of three meetings. Before implementing the actions, the researcher conducted a pre-test to measure the students' writing ability. The problems encountered by the students in writing were the structure of the text, grammar/language use and diction. Some steps were also conducted to determine the problem.

The result of the research showed that there were some students' improvements in writing descriptive texts using pictures. The students could use the appropriate vocabulary in their writing. They could write a text with more detailed information based on the picture and used correct capitalization, spelling, and punctuations; they produced longer paragraph with sufficient supporting details. The students could get the ideas and inspirations to write a descriptive text after they had seen the picture and knew the steps.

Several things related to the implementation of the PWIM were found from the observation notes. There are always strengths and weaknesses. Each of them was discussed comprehensively by the researcher with her collaborator so that it could become input for future improvements. So that in the end, all the short comings were overcome. As an example, at the beginning of the actions the teacher still had difficulties with several things such as time management and class control but then soon after that she corrected her mistakes so that they did not happen again in the next phase. From the students' side, at first they looked confused, puzzled and afraid when they were asked to write. They still had difficulties in expressing their ideas, their opinions and their thoughts, and they still found it hard to combine the new vocabularies into a sentence and they were 
also less motivated to follow the teachinglearning processes. Those problems were discussed and analyzed until the PWIM became the solution to those problems so they could be resolved. Therefore, the researcher can say that the PWIM gave a positive impact for the teaching learning processes in her speaking class.

There were ten stages did by the students throughout the three cycles. Firstly, they had to observe the pictures chosen by the teacher. The students were really enthusiastic in describing pictures. Pictures did not only bring images of reality, but also has function as a fun element in the class. Through the pictures students can see and imagine what things are inside. Moreover, through pictures would ease them to recall vocabulary to compose a paragraph. Secondly, the students identify the pictures such as the objects, the events, the situation, as well as the actions happen in the picture. Third, students were asked to label the picture. In this activity, the students named the pictures and uttered the word loudly. This was done in order to drill the student on vocabulary mastery and got feedback from the other students. Fourth, the student had to read and review the words they had written in stage four. The sixth, students repeated the activity in stage five. In this stage, the students uttered some words being written and reviewed their words related to the picture. With their friends in their group they corrected their mistakes with guidance from their teacher. Finally, they had to re-record what they said after it had been corrected and ensure that their corrected speech was written in their notebooks for future learning and review outside of class. Through these activities the teacher-centered class time was reduced and the studentcentered class time was increased. Seventh stage was the time for students to add some information about the picture. In this stage, through the guidance of the teacher, the students add some words to expand the information about the picture. The teacher also guided the students to write the tittle of their writings. The next stage was students constructed the words they have been listed into a sentence and a paragraph. Finally, the teacher read and reviewed the students' writing.

When the observations of the learning processes were being done during the first cycle, the students were really busy with their activities. Most of the students were motivated to participate more in the teachinglearning processes for writing descriptive text since the PWIM reduce their boredom during the teaching-learning processes. They became more motivated at constructing the paragraph in English and were more active in the teaching-learning processes because the PWIM gave them more guidance in a clear stage to practice writing during the class activities. They felt more comfortable to compose a paragraph in front of their lecturer as well as in front of their classmates. They were more interested in learning writing for they could compose paragraph and comprehend the material given by the teacher. They could assess their own work through the reading and reviewing activities and then they could improve their writing ability as they corrected their problems. Using the PWIM had enabled them to develop social skills in the teaching-learning processes, which gave them self-esteem to show their ability in using English. It also helped them to solve their problems in learning writing descriptive text because they could share with their friends as one of a pair or a group and hence they got feedback from their friends.

\section{Result from test in each cycle}

The students' tests were scored by using the scoring rubric listed in Table 2 . The maximum score for each aspect was 4 and the minimum score was 1 . At the end of each cycle, the researcher did the reflections. The result of the research showed that there were some students' improvements in writing descriptive texts using PWIM. Based on the results from their writings, it was found that the writing skills of the students improved further within each cycle. The scores from each student in all four tests are set out in Figure 1. 
Mira Ermita, Emzir, \& Ninuk Lustyantie

Picture word inductive model for better descriptive text writing

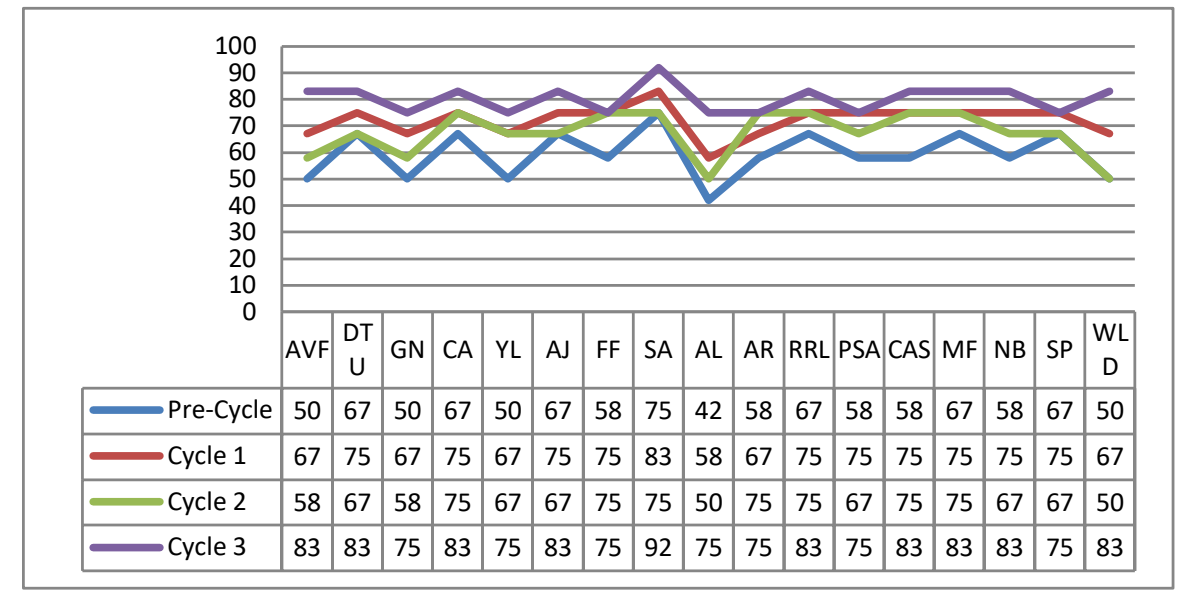

Figure 1. Students' score from all four writing tests

To compare the test results between the pretest and between each test, the mean scores from each test, the percentage of the class achieving the passing score, and the improvement in the mean score from one test to the next were calculated and are set out in Table 5 .

Table 5. Students' score viewed from average, category, and passing grade

\begin{tabular}{lccc}
\hline \multicolumn{1}{c}{ Test } & Average Score & Category & Passing Score \\
\hline Pre-cycle & 59 & Poor & $6 \%$ \\
Cycle 1 & 72 & Good & $65 \%$ \\
Cycle 2 & 67 & Fair & $41 \%$ \\
Cycle 3 & 80 & Excellent & $100 \%$ \\
\hline
\end{tabular}

Based on the result of the tests in each cycle sets in Table 5, it can be narrated that the results of the test were fluctuate. In the pre-cycle the students writing ability was low. The average score was only 59 and it belongs to "Poor" category. Moreover, the passing grade was only $6 \%$. In cycle 1 the average score was 72 . It means that the score was in the "Good" category. Nevertheless, the passing score had not been reached. It just reached $65 \%$. In cycle 2 , the result of the test was even getting worse. The average score was under the 70 or only 67 . This score was categorized into "Fair", and the passing grade also decreased became $41 \%$. Yet, the students' score was increased in cycle 3 . The average score was 80. It was in "Excellent" category. The passing score was $100 \%$. It was meant that all the students passed the passing grade. Figure 2 shows the improvements in the mean scores of students in each test. Besides, The students' average score in the three aspects of writing also increased. It was set in Figure 3.

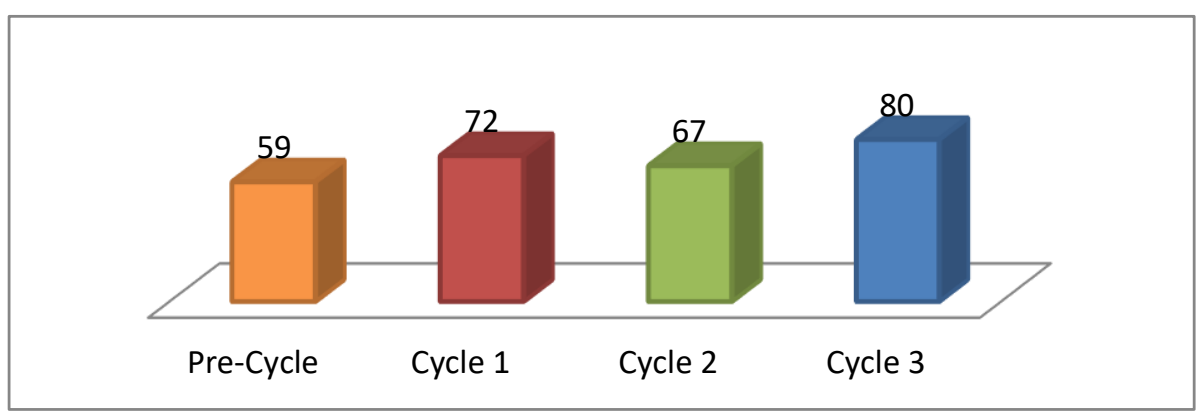

Figure 2. Students' mean scores of each cycle 


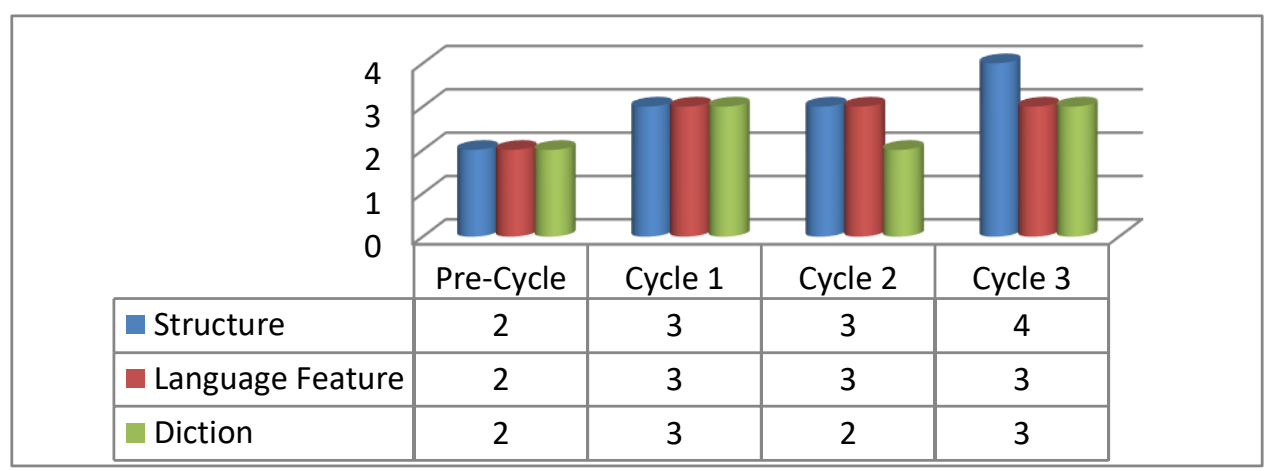

Figure 3. Students' mean scores of each aspect of writing

The mean score of structure improved from 2 in pre-cycle to 3 in cycle 1 and cycle 2 , and increased again became 4 in cycle 3 . The mean score of language feature improved from 2 in pre-cycle test to 3 in cycle 1,3 in cycle 2 , and 3 in cycle 3 . The students' skill in diction also improved from 2 in pre-cycle to 3 in cycle 1 , yet it decreased to 2 in cycle 2 and increased again to 3 in cycle 3 .

The students' skill in exploring the ideas improved. The students were more fluent in expressing the ideas and their writing was logical. They were able to organize the generic structure of the texts. To wrap up the result is supported by Kurniawan and Lubis (2015) stating that PWIM increased students creativity during teaching and learning process. The students felt comfortable while make a paragraph in a good organization and paragraphing according to the generic structure of a descriptive text.

The students' skill in grammar also improved. The students were able to differentiate between present tense and past tense. They began to be able to choose appropriate tenses for their writing. It can be said that by the end of the action, the students could use the appropriate vocabulary in their writing. PWIM consists of images that are familiar with students. Educators use PWIM in class with small groups, and individuals to lead them to ask questions about words, add words for them to read and write vocabulary (Indra \& Sudartini, 2015; Kartika, Sofian \& Suhartono, 2012). This is to make students able to identify easily. In addition Kartika, Sofian, and Suhartono (2012) also said that
PWIM is an inquiry into the art-oriented model of language that uses images containing foreign objects and actions to obtain words from listening to children and talking.

The students' skill in language use also improved. The students made better sentences and used simple present tense, noun phrase, conjunction, and adverb in a better way. The students' skill in mechanics also improved. The students' skill in writing was better organized in paragraphing and also much better in spelling, capitalization, and punctuation. Besides, the students could apply the appropriate tense in their writing. They had enough opportunity to write; the teaching-learning focused more on writing skill. Through this action, the students had more practices in writing descriptive texts using pictures. They could create a better writing than before including in constructing the present sentences by using simple present tense. This finding was supported by the research conducted by the opinions above are supported by Shaman (2014), PWIM helps students learn to read and write, by activating the student scheme, it also helps develop vocabulary knowledge, and spelling for learning English (Soviyah \& Etikaningsih, 2018). They could write a text with more detailed information based on the picture and used correct capitalization, spelling, and punctuations; they produced longer paragraph with sufficient supporting details. The students could get the ideas and inspirations to write a descriptive text after they had seen the picture and knew the steps. The pictures gave them a stimulus so that 
they could have something to write in their paper.

The results of the test also support the positive improvements. Moreover, their attitude towards writing had changed to be better. It was not hard to ask them to write a descriptive text. They were also interested and motivated to join and to get involved in teaching and learning process. They became more active in teaching and learning process. They showed positive attitudes towards writing lesson. The students became more active and enthusiastic both in responding to the researcher and finishing the exercises given. They asked questions to the teacher and also answered the teacher's question.

The use of picture in the teaching learning process of writing skill could make the students motivated and confident when they were asked to write in groups and individually by seeing the picture first. They did their writing without being asked many times and did not complain anymore. By seeing the pictures, the students could spend shorter time when they were asked to write and most of the students could finish their writing on time. It is because the pictures could help them by presenting certain topic which can be written down. Some students discussed actively about the topic in the pictures in their own group after they saw the pictures. Their motivation could be seen from their activity during the action. They paid close attention when the researcher showed the pictures. They felt comfortable and did not look bored. It was easier for students to write the story based on the picture because they still remembered what they saw. This finding is supported by Muttaqin (2015) Nurleni (2018), Riyadi (2017), Sepyanda Mukhaiyar, \& Kusni (2013), and Suraya (2017) that PWIM can improve students' writing skills. Hence the results showed that the use of the PWIM was a success. The students enjoyed their lessons more, and were more motivated, interested and confident during the teaching learning sessions.

\section{CONCLUSION}

Based on the results of the research, it could be concluded that the use of PWIM the students' skill in writing descriptive text in three aspects. The aspects were: the structure, language feature, and diction. The most significant improvement was in the aspect of structure. The use of picture that applied in writing made the students interested to the media. They had high motivation to join the teaching and learning process and they had good spirit to learn English while the PWIM is applied in writing class. The students paid attention more when the researcher used and showed the pictures. They felt comfortable and they did not look bored. It was easier for the students to write the descriptions on the paper because they still remembered what they saw while the teacher showed the pictures. It proved that the use of picture as the media in the teaching and learning process improved the students' writing skill.

\section{ACKNOWLEDGEMENT}

In this part, the researchers need to express many thanks to the persons who helped in the research. First, the researchers would like to say thanks to Educational fund management institution of Republic of Indonesia (LPDP) who gave financial support. Second, the researchers would like to say thanks to team of University of Jambi, Indonesia who provided good service for the researchers during the research.

\section{REFERENCES}

Abbas, A. M., \& Tawfeeq, H. M. (2018). The effects of direct and indirect corrective feedback on accuracy in second language writing. English Language Teaching, 11(6), 33-40.

Aji, R. S. (2013). Upaya meningkatkan keterampilan menulis karangan deskripsi dengan menggunakan media gambar. Universitas Negeri Yogyakarta.

Aljatila, L. O. R. (2015). Meningkatkan keterampilan menulis karangan deskriptif melalui model kooperatif tipe round table. Jurnal Humanika, 3(15), 1-14.

Anderson, M., \& Anderson, K. (1997). Text types in English. Australia: Macmillan Education Australia, 95.

Budiharto, R. A. (2019). Native language interference on target language writings of Indonesian EFL 
students: An exploratory case study. Indonesian EFL Journal, 5(1), 107-116.

Chanyoo, N. (2018). Cohesive devices and academic writing quality of Thai undergraduate students. Journal of Language Teaching and Research, 9(5), 994-1001.

Dadi, L. S. (2015). How to write a short essay in English academic writing. Bandung: Alfabeta, 15.

Derewianka, B. (2000). Exploring how texts work. Sydney: Primary English Teaching Association, 22.

Emilia, E. (2010). Teaching writing: Developing critical learners. Bandung: Rizqi Press, 35.

Fadhly, F. Z., Hasanah, N., \& Agustiana, V. (2017). Mental process of writing for academic purposes: A case study of Indonesian writers. Indonesian EFL Journal, 3(2), 203-214.

Feng, C. C. (2011). The cooperative classroom: Scaffolding EFL learners' English literacies through the picture word inductive model. University of Toronto.

Finoza, L. (2013). Komposisi bahasa Indonesia. Jakarta: DIKSI, 11.

Indra, A. N., \& Sudartini, S. (2015). Improving students' ability in writing narrative texts through the use of picture word inductive model. English Language Teaching, 8(5), 1-5.

Jam, B., \& Shahin, L. (2012). Investigating the efficiency of two writing strategies among Iranian EFL learners: Translated writing vs. reading to write. Research in Applied Linguistics, 3(2), 67-81.

Joyce, B., Weil, M., \& Calhoun, E. (2009). Models of teaching (Eighth). USA: Pearson Education, Inc, 107.

Kamariah, A., Husain, D., Atmowardoyo, H., \& Salija, K. (2018). Developing authentic-based instructional materials for writing skill. Journal of Language Teaching and Research, 9(3), 591599.

Kartika, Z., Sofian, \& Suhartono, L. (2012). Improving students writing descriptive text by using the picture word inductive model. University Tanjungpura.

Knapp, P., \& Watkins, M. (2005). Genre, text, grammar technologies for teaching and assessing writing. Australia: University of New South Press.

Kurniawan, \& Lubis, D. T. A. (2015). Picture word inductive model strategy in writing descriptive paragraph. J-SHMIC, 2(4), 31-39.

Mcdonald, K. A. (2010). The picture word inductive model: An effective model for vocabulary instruction. The University of British Columbia.

Mertler, C. A. (2009). Action research: Teachers as research in the classroom. USA: SAGE Publication, Inc., 29.

Miy, D. G. (2012). How to write a descriptive text. Universidad Virtual del Estado de Guanajuato.
https://journal.uniku.ac.id/index.php/IEFLJ/index

Muttaqin, M. Z. (2015). Improving writing ability through picture word inductive model. Muhammadiyah University of Jember.

Niño, F. L., \& Páez, M. E. V. (2018). Building writing skills in English: Analysis of strategies based on literature and creativity. English Language Teaching, 11(9), 102-117.

Nurani, S., \& Rosyada, A. (2017). Implemented picture word inductive model in developing students' communicative competence. Lingua Cultura, 11(5), 25-30.

Nurdianingsih, F. (2018). Language learning strategy and students' writing skill achievement: A correlational research. Indonesian EFL Journal, 4(7), 23-31.

Nurleni. (2018). The influence of using picture word inductive model strategy toward students' descriptive text writing. Raden Intan State Islamic University.

Ratminingsih, N. M., Marhaeni, A. A. I. N., \& Vigayanti, L. P. D. (2018). Self-assessment: The effect on students' independence and writing competence. International Journal of Instruction, 11(3), 277-290.

Riyadi, D. (2017). The use of picture word inductive model strategy in improving a descriptive text writing. Tanjungpura University.

Rohmat, N., \& Sadikin, I. S. (2019). The impact of peer response on EFL learners' writing descriptive text. Indonesian EFL Journal, 5(1), 59-66.

Sepyanda, M. (2013). The effect of picture word inductive model and students' self-efficacy toward their writing skill of descriptive text. Lingua Didaktika, 6(2), 95-101.

Sepyanda, M., Mukhaiyar, \& Kusni. (2013). The effect of picture word inductive model and students' self-efficacy toward their writing skill of descriptve texts. Journal English Language Teaching, 1(1), 111-119.

Shaman, S. (2014). Using the picture word inductive model to teach English vocabulary. ORTESOL Journal, 31, 49-50.

Soviyah, \& Etikaningsih, D. R. (2018). Instagram use to enhance ability in writing descriptive texts. Indonesian EFL Journal, 4(17), 32-38.

Suraya, D. (2017). The effect of using picture word inductive model on teaching descriptive text writing. Tanjungpura Universiry.

Swartzendruber, K. (2007). The picture word inductive model and vocabulary acquisition. Proceedings of the 3rd Annual GRASP Symposium, Wichita State University, (1999), 177-178.

Syarifah, E. F., \& Emiliasari, R. N. (2019). Project based learning to develop students' ability and creativity in writing narrative story. Indonesian EFL Journal, 5(1), 85-94.

Urrutia, L. J., \& Gutierrez, A. S. M. (2011). Adolescents' awareness of environmental care: 
Mira Ermita, Emzir, \& Ninuk Lustyantie

Picture word inductive model for better descriptive text writing

Experiences when writing short descriptive texts in English. PROFILE, 13(1), 11-30.

Weigle, S. C. (2002). Assesing writing. UK: Cambridge University Press, 144.
Yuniyarsih, P., \& Saun, S. (2014). Using picture word inductive model to teach students in writing a descriptive text. JELT, 2(2), 192-199. 